
ISSN : 2615-1995, E-ISSN : 2615-0654

J. Madani., Vol. 2, No. 2, September 2019 (258 - 269)

(C)2018 Lembaga Kajian Demokrasi

MADANI

dan Pemberdayaan Masyarakat (LKD-PM)

\title{
Penggunaan Metode Bercerita Untuk Meningkatkan Kemampuan Menyimak Anak Usia Dini Kelompok B di TK Mawar Indah Kecamatan Medan Petisah
}

\author{
Mei Lyna Girsang \\ Fakultas Ilmu Pendidikan, Universitas Sari Mutiara Indonesia \\ meilyna_girsang@yahoo.com \\ Muhammad Rasyid Ridlo \\ Fakultas Ilmu Budaya, Universitas Sumatera Utara \\ rasyidridlo28@gmail.com \\ Aprilla Utari \\ TK Mawar Indah Medan \\ aprillautari1992@gmail.com
}

\begin{abstract}
Abstrak
Tujuan dari penelitian ini adalah peningkatan kemampuan menyimak siswa Kelompok B TK Mawar Indah dengan metode Story Telling. Penelitian ini bertujuan untuk meningkatkan kemampuan menyimak anak Kelompok B TK Mawar Indah melalui penggunaan metode bercerita. Penelitian ini merupakan penelitian tindakan kelas yang dilakukan secara kolaboratif antara peneliti dan guru kelas. Subjek penelitian ini adalah 20 anak kelompok B TK Mawar Indah, yang terdiri dari 8 anak laki-laki dan 12 anak perempuan. Objek penelitian ini adalah kemampuan menyimak. Teknik pengumpulan data dilakukan melalui tes perbuatan.Data penelitian dianalisis secara deskriptifkuantitatif. Target dari hasil penelitian ini yaitu peningkatan kemampuan menyimak anak dengan kriteria sangat baik miniml mencapai 81\%. Pada kondisi awal, kemampuan menyimak anak diperoleh hasil rata-rata sebanyak 42,5\%. Setelah dilakuan tindakan pada Siklus I, peningkatan kemampuan menyimak diperoleh hasil rata-rata sebanyak 76,25\%. Penelitian ini dihentikan sampai Siklus II karena telah memenuhi kriteria indikator keberhasilan dengan hasil rata-rata mencapai hingga 97,5\%.
\end{abstract}

Kata kunci: Kemampuan Menyimak, Metode Bercerita

\begin{abstract}
The aim of this classroom action research is to increase children's Listening ability in group B TK Mawar Indah through Story Telling Method. This is a classroom action research which is collaboratively piloted by researchers and the teachers. The sample of the research were 20 childrens of group B TK Mawar Indah consisting of 8 boys and 12 girls. The object of the study is the listening ability. Data collection is done through action test. The data is analyzed by using quantative descriptive. The target of this research is the improvement of listening ability of the children with a very good criteria at least $81 \%$. The result showed that listening ability of children increased after being given action through story telling. The increasing can be seen from the initial condition of listening ability of group B children by $42,5 \%$, then in the first cycle increased to $76,25 \%$ and then increased in the second cycle to $97,5 \%$. The researches were stopped in the cycle II because the indicator has been fullfilled.
\end{abstract}

Keywords: listening ability, storytelling method 


\section{PENDAHULUAN}

Golden age adalah salah satu tahap perkembangan yang akan dialami oleh setiap anak. Fase ini terjadi pada usia 0-6 tahun atau biasa disebut sebagai usia dini. Fase golden age merupakan fase optimal seorang anak untuk menyerap informasi yang didapat dari lingkungannya. Anak usia dini yang berada dalam fase ini harus diberikan stimulus dengan baik untuk mengoptimalkan kemampuan kognitif, afektif dan motorik.

Anak usia dini yang berada dalam tahap golden age memerlukan stimulus terhadap motorik kasar seperti kemampuan menciptakan sesuatu (kreatifitas), dan motorik halus seperti kemampuan pengetahuan, kemampuan menalar, seni dan bahasa, serta kemampuan mengontrol emosi agar anak mencapai perkembangan dan pertumbuhan yang optimal sesuai dengan karakter masing-masing anak.

Stimulus atau rangsangan-rangsangan yang diberikan kepada anak usia dini dapat diupayakan dalam Pendidikan Anak Usia Dini (PAUD) yang mengacu pada Undang-undang Nomor 20 Tahun 2003 tentang sistem Pendidikan Nasional Pasal 1 Ayat 14. Pendidikan Anak Usia Dini (PAUD) bertujuan menyiapkan fisik dan mental anak agar mereka siap ketika berada di jenjang pendidikan yang lebih tinggi serta lingkungan masyarakat sekitarnya.

Penyelenggaraan PAUD difungsikan sebagai fasilitas bagi anak untuk menumbuhkembangkan seluruh aspek kepribadian anak yang meliputi aspek agama, moral, kognitif, bahasa, sosial emosional dan seni, serta fisik-motorik. Hal ini sesuai dengan penjelasan Peraturan Menteri Pendidikan dan Kebudayaan Republik Indonesia Nomor 137 tahun 2014 pasal 1 ayat 2 tentang Standar Tingkat Pencapaian Perkembangan Anak (STTPA).

Perkembangan aspek bahasa memiliki peran yang sangat signifikan dalam perkembangan anak usia dini, karena bahasa adalah bagian dari komunikasi dan interaksi anak dengan lingkungan sosialnya. Kemampuan bahasa yang baik menjadi tolok ukur keberhasilan komunikasi dan interaksi sosial anak. Kemampuan bahasa yang harus dimiliki diantaranya menyimak, berbicara, membaca, dan menulis (Bromley, 1992: 1.190).
Dalam tulisan ini peneliti meneliti kemampuan menyimak karena kemampuan menyimak merupakan kemampuan paling dasar dalam bahasa. Menyimak sangat penting dalam interaksi komunikatif, karena melalui menyimak seseorang dapat memahami dan merespon sesuatu yang dikatakan oleh pembicara. Melalui menyimak pembendaharaan kata anak dapat bertambah, dengan demikian kemampuan menyimak perlu dikembangkan sedini mungkin karena sebagai dasar pengembangan kemampuan berbahasa.

Anderson (1972:68) mendefinisikan menyimak sebagai kegiatan mendengarkan dengan penuh pemahaman dan perhatian serta apresiasi. Definisi menyimak yang lebih rinci dikemukakan oleh Tarigan (1986:9-10), ia menyatakan bahwa menyimak adalah sebuah proses mendengarkan lambang-lambang ujaran lisan disertai perhatian, pemahaman apresiasi serta interpretasi yang bertujuan untuk mendapatkan informasi serta memaknai pesan yang disampaikan oleh lawan bicara. Dari penjelasan diatas dapat disimpulkan bahwa menyimak adalah mendengarkan, menginterpretasikan, serta memahami pesan atau materi dengan penuh perhatian dan sungguh-sungguh agar penyimak dapat memahami makna pesan dan materi yang dikatakan oleh pembicara. Salah satu kemampuan berbahasa yang diajarkan di Taman Kanak-kanak adalah keterampilan menyimak. Kemampuan menyimak perlu dipusatkan dan dikembangkan sedini mungkin karena sebagai dasar kemampuan berbahasa lainnya. Pentingnya kemampuan menyimak dalam komunikasi interaktif memang sangat nyata.

Kemampuan menyimak yang baik tidak dimiliki oleh semua anak usia dini. Seperti yang terjadi pada siswa TK Mawar Indah kelompok B yang sekitar $70 \%$ memiliki kemampuan menyimak yang sangat rendah. Rendahnya kemampuan menyimak ini terindikasi dari feed back anak terhadap pembelajaran yang tidak maksimal, diantaranya kurangnya respon terhadap guru dan lambat dalam menjawab pertanyaan guru. Hal terburuk dari rendahnya kemampuan menyimak adalah sikap acuh tak acuh anak ketika pembelajaran berlangsung, bahkan sikap jahil anak terhadap teman sekelasnya. Faktor yang 
mendorong munculnya respon negatif tersebut adalah metode pembelajaran yang tidak variatif, serta kurangnya metode permainan sehingga anak-anak merasa jenuh dan bosan. Selain itu, proses belajar yang menggunakan metode konvensional, seperti ceramah, membuat anak-anak mengantuk sehingga sulit untuk menyimak pesan yang disampaikan guru, dan ketika guru bertanya tentang pelajaran anak tidak mampu menjawab dan menjelaskan.

Kemampuan menyimak anak bisa terlihat saat guru menceritakan sebuah cerita kepada mereka dan setelah mereka mendengar cerita tersebut apakah bisa menyebutkan tokoh, tempat, atau objek lainnya dalam cerita atau tidak. Kasus yang terjadi di TK Mawar Indah, hanya 6 dari 20 anak yang mampu menyimak cerita dengan baik. Penggunaan media yang terkesan biasa saja di mata anak adalah salah satu faktor penyebabnya. Hal inilah yang menarik perhatian peneliti untuk meneliti peningkatan kemampuan menyimak cerita melalui media gambar pada anak usia 5-6 tahun di TK Mawar Indah.

Berdasarkan permasalahan diatas yang terjadi di TK Mawar Indah, peneliti tertarik dengan penggunaan metode bercerita sebagai upaya peningkatan kemampuan bahasa anak usia dini kelompok B di TK Mawar Indah, khususnya menyimak. Penulis memilih metode bercerita karena melalui bercerita dengan menggunakan buku cerita bergambar dapat menarik perhatian anak sehingga anak memiliki keinginan untuk menyimak serta mendengarkan cerita yang dibacakan guru. Guru dapat membaca cerita dengan alat peraga seperti boneka tangan, boneka jari, serta buku cerita bergambar yang dapat membuat anak menjadi senang. Selain alat peraga guru juga harus mampu membacakan cerita dengan mimik wajah dan intonasi suara serta gaya yang menarik perhatian. Metode bercerita sangat penting digunakan di PAUD karena melalui bercerita anak usia dini dapat menyimak dan mendengarkan dengan penuh perhatian.

Bercerita adalah sebuah kegiatan menyampaikan pesan secara lisan baik berupa informasi ataupun cerita fantasi. Saat menyampaikan cerita fantasi biasanya pembicara menggunakan media tertentu agar menarik perhatian lawan bicara atau pendengar. Muslichatoen (2004: 157) mengatakan bahwa dengan menggunakan metode bercerita dalam pembelajaran, anak akan mendapatkan pengalaman belajar. Dengan kata lain, melaui metode bercerita , guru bisa sekaligus menyampaikan materi pembelajaran bagi anak.

Ada beberapa hal yang harus diperhatikan saat menggunakan metode bercerita dalam proses pembelajaran. Pertama, guru harus mampu memilih cerita yang tidak hanya menarik namun sarat akan pesan, nasihat, dan nilai moral untuk diteladani dalam kehidupan sehari-hari. Kedua, guru harus mampu memahami keterkaitan antara cerita yang disajikan dengan kehidupan anak-anak, sehingga esensi atau pesan dari cerita tersebut dapat ditangkap dan dicerna dengan mudah oleh anak. Selain dapat menangkap dan mencerna pesan, melaui metode bercerita anak-anak diharapkan mampu mengembangkan kemampuan bahasa lainnya, yaitu kemampuan berbicara. Dengan metode bercerita anak mampu untuk menceritakan kembali cerita yang disampaikan kepadanya dengan bahasanya sendiri. Dengan demikian, kemampuan menyimak anak berpengaruh terhadap kemampuan bahasa lainnya.

Dalam penelitian ini peneliti memilih cerita yang belum pernah didengar anak disekolah, yaitu cerita yang berjudul "Ulat dan Bunga Matahari" dan cerita ini dibuat oleh peneliti sendiri. Peneliti menggunakan cerita hanya 1 cerita saja agar anak mampu memahami isi cerita dengan baik. Penelitian ini dilakukan selama 4 kali pertemuan. Peneliti juga memilih cerita ini karena ceritanya mengandung makna yang menarik dan dekat dengan lingkungan anak sehari-hari sehingga anak dapat menyimak isi cerita dengan mudah. Oleh sebab itu, peneliti memilih "Metode Bercerita Untuk Meningkatkan Kemampuan Menyimak Anak Pada Kelompok B Di TK Mawar Indah, Kecamatan Medan Petisah".

Berdasarkan latarbelakang dapat disimpulkan rumusan masalah yaitu "Bagaimana metode bercerita dapat meningkatkan kemampuan menyimak pada angka kelompok B di TK Mawar Indah".

Tujuan Penelitian ini adalah "Untuk mening- 
katkan kemampuan menyimak melalui metode bercerita pada anak kelompok B di TK Mawar Indah, Kec. Medan Petisah TA 2017/2018".

Adapun manfaat penelitian yang dapat diperoleh dari penelitian ini yaitu secara Teoritis penelitian diharapkan dapat memberikan sumbangan pemikiran ilmiah dalam memajukan pendidikan anak usia dini khususnya pada upaya meningkatkan kemampuan menyimak melalui metode bercerita. Manfaat seacra Praktis antara lain; sisw dapat meningkatkan keterampilan bahasa anak dengan bertambahnya kosa kata dan menjadikan anak lebih kreatif sehingga motivasi belajar anak menjadi meningkat; guru dapat memberikan wawasan kepada guru agar dapat menerapkan metode bercerita dalam mengembangkan kemampuan bahasa anak khususnya menyimak; sekolah dapat memberikan sumbangan pemikiran, ide dan saran bagi perbaikan pembelajaran disekolah khususnya mengenai pentingnya penggunaan metode bercerita bagi pengembangan kemampuan menyimak anak dalam pembelajaran; peneliti dapat menambah wawasan, kemampuan dan pengalaman dalam meningkatkan kompetensinya sebagai calon guru.

Sebelum membahas tentang kata menyimak, terlebih dahulu perlu membedakan tiga istilah dalam menyimak, yaitu mendengar, mendengarkan dan menyimak. Dalam bahasa Inggris padanan kata mendengar adalah To Hear, sedangkan kata menyimak adalah To Listen. Dalam KBBI menyimak diartikan sebagai mendengarkan dan memperhatikan dengan seksama apa yang diucapkan oleh orang lain. Anderson dalam bukunya (1972: 69) mengemukakan hal yang sama bahwa menyimak adalah kegiatan mendengarkan dengan memusatkan perhatian dan penuh pemahaman serta apresiasi. Cahyani dan Hodijah (2007:8) "menyimak adalah keterampilan memahami bahasa lisan yang bersifat sementara". Definisi menyimak yang lebih rinci dikemukakan oleh Tarigan (1986:9-10), ia menyatakan bahwa menyimak adalah sebuah proses mendengarkan lambang-lambang ujaran lisan disertai perhatian, pemahaman apresiasi serta interpretasi yang bertujuan untuk mendapatkan informasi serta memaknai pesan yang disampaikan oleh lawan bicara. Disamping itu, menurut marhijanto (1995: 520) "menyimak adalah mendengarkan baik-baik terhadap ucapan orang lain (sambil meresapkan dalam hati). Sejalan dengan hal diatas, Sabarti juga mengemukakan bahwa menyimak adalah suatu proses yang mencakup kegiatan mendengarkan bunyi bahasa, mengidentifikasi, menginterpretasi, menilai dan mereaksi atas makna yang terkandung didalamnya. Dari beberapa definisi menyimak di atas, kita dapat menarik kesimpulan bahwa menyimak adalah kegiatan mendengarkan dengan memusatkan perhatian ujaran lisan lawan bicara yang bertujuan untuk memperoleh, memahami dan menginterpretasi pesan atau informasi yang disampaikan pembicara.

Sabarti dalam bukunya (1992: 149) menyebutkan fungsi-fungsi menyimak diataranya, (1) menjadi dasar belajar bahasa anak, (2) menunjang kemampuan bahasa lainnya (berbicara, membaca dan menulis), (3) alat komunikasi verbal lisan, (4) sarana mendapatkan informasi dan pengetahuan. Sejalan dengan pendapat sebelumnya, Hunt dalam Tarigan (1986:55) mengemukakan fungsi menyimak selain sebagai sarana memperoleh informasi. Lebih lanjut, Hunt berpendapat bahwa menyimak bertujuan untuk membentuk aspek kepribadian antar pembicara seperti membangun hubungan pribadi yang efektif, memberikan feed back yang baik, serta mengumpulkan data agar dapat membuat keputusan yang masuk akal. Berdasarkan fungsi-fungsi menyimak di atas, kita simpulkan bahwa menyimak:

1. Menjadi langkah awal pemerolehan bahasa, baik bahasa ibu maupun bahasa asing. Di ini menyimak dalam artian mendengarkan (to listen), menjadi sarana mendapatkan kosa kata bahasa yang diajarkan kepadanya. Sebagai contoh, balita yang mendengarkan ujaran-ujaran ibunya seperti kata papa, ayah dan lainnya secara berulang-ulang.

2. Menjadi dasar pembelajaran memahami bahasa tulis yaitu membaca dan menulis. Maksudnya, dengan menyimak seorang anak mampu mengidentifikasi suara dan bunyi sehingga anak akan mampu dan siap untuk diajarkan membaca.

3. Menunjang keterampilan berbahasa lainnya, 
maksudnya jika kita menyimak hasil dari pembicaraan maka perbendaharaan kita bertambah sehingga kemampuan bahasa lisan maupun tulisan anak meningkat.

4. Memperlancar komunikasi lisan, maksudnya apabila kita menyimak pembicaraan dari seseorang maka kita memahami dan mengerti isi dan makna dari apa yang sedang dibicarakan sehingga komunikasi diantara keduanya berjalan dengan lancar.

5. Menambah informasi atau pengetahuan, maksudnya jika mendapatkan informasi dan pengetahuan tidak hanya dari pembaca saja, dengan menyimak sebuah cerita, ceramah, diskusi, maupun seminar dengan baik kita juga akan mendapatkan informasi dan menambah pengetahuan kita.

Menyimak adalah suatu proses yang memiliki beberapa tahapan. Logan (1972:39) dan Loban (1969:243) menyatakan ada lima tahapan dalam proses menyimak, antara lain:

1. Tahap Mendengar (Hearing). Ditahap mendengar, kita hanya perlu mendengar segala ujaran yang disampaikan oleh pembicara.

2. Tahap Memahami (Understanding). Setelah mendengar, kita dituntut untuk memahami dengan benar pesan dari pembicara.

3. Tahap Menginterpretasi (Interpreting).Tahap interpreting memerlukan kecermatan dan ketelitian dari penyimak sehingga ia bisa menafsirkan pesan tersirat dari pembicaraan.

4. Tahap Evaluasi (Evaluating). Tahap evaluasi penyimak harus mampu mengevaluasi apakah pesan yang disampaikan pembicara baik atau tidak.

5. Tahap Menanggapi (Responding). Penyimak memberikan tanggapan atas pesan yang disampaikan pembicara, tanggapan ini bisa berupa persetujuan, penerimaan atau penolakan atas pesan tersebut.

Menyimak merupakan suatu kegiatan yang melibatkan beberapa kegiatan lainnya diantaranya mendengar, memahami, menafsirkan, mengevaluasi dan memberikan tanggapan atas gagasan, pesan, atau yang telah disimak. Untuk mencapai keberhasilan dalam mengidentifikasi, menginterpretasi dan memaknai bahan simakan di- pengaruhi oleh beberapa faktor. Henry G Tarigan (1991: 104-107) menjelaskan efektifitas menyimak dipengaruhi oleh faktor berikut:

a. Fisik

Faktor fisik yang mempengaruhi keberhasilan menyimak yaitu keadaan fisik penyimak dan lingkungan terjadinya proses menyimak.

b. Psikologis

Faktor Psikologis meliputi masalah personal antara pembicara dan penyimak, seperti prasangka, egosentris, pikiran sempit, bosan, dan masalah lainnya yang dimiliki pembicara dan penyimak.

c. Pengalaman

Pengalaman di sini adalah penyimak dan pembicara telah melakukan interaksi sebelumnya. Pengalaman yang kurang baik yang dimiliki penyimak memengaruhinya untuk tidak ingin mendengarkan pembicara di kesempatan berikutnya, begitupun sebaliknya.

d. Sikap

Penyimak biasanya memilah topik tertentu. Jika penyimak menyukai atau menyetujui topik yang sedang dibicarakan biasanya ia akan memberikan sikap yang baik ketika menyimak.

e. Motivasi

Keberhasilan menyimak sangat bergantung pada motivasi seseorang untuk menyimak.

f. Jenis Kelamin

Laki-laki dan perempuan memiliki sikap yang berbeda ketika menyimak.

Menurut Moeslichaton (2004:7) metode adalah bagian dari strategi agar tujuan tercapai. Menurut Permendikbud Nomor 146 Tahun 2014 metode-metode pembelajaran dalam pendidikan anak usia dini yaitu; (1) Metode Bercerita, (2) Metode demontrasi, (3) Metode bercakap-cakap, (4) Metode pemberian tugas, (5) Metode sosiodrama atau bermain peran, (6) Metode karya wisata, (7) Metode proyek, dan (8) Metode eksperimen. Dalam penelitian ini metode yang digunakan oleh penulis yaitu metode story telling atau bercerita.

Bercerita adalah sebuah kegiatan menyampaikan pesan secara lisan baik berupa informasi ataupun cerita fantasi. Saat menyampaikan cerita fantasi biasanya pembicara menggunakan 
media tertentu agar menarik perhatian lawan bicara atau pendengar. Menurut Prof. Dr. Tampubolon (1991:50) "bercerita kepada nak memainkan peranan penting bukan saja dalam menumbuhkan minat dan kebiasaan membaca, tetapi juga dalam mengembangkan bahasa dan pikiran anak". Menurut Moeslichatoen (2004:157) "metode bercerita merupakan salah satu pemberian pengalaman belajar bagi anka TK dengan membawakan cerita kepada anak secara lisan". Melalui metode bercerita anak mendapat pengalaman serta pengetahuan yang akan disampaikan oleh guru melalui ceritanya. Disamping itu, menurut Marhijanto (1995:128) "Bercerita adalah berkisah, mendongeng, menuturkan suatu kejadian kepada orang lain”.

Dalam kegiatan pelaksanaan pembelajaran di TK metode bercerita dilaksanakan dalam upaya memperkenalkan, memberikan keterangan, atau penjelasan tentang hal baru dalam rangka menyampaikan pembelajaran yang dapat mengembangkan berbagai potensi dasar anak. Menurut Musfiroh (dalam azizah, 2015), "metode bercerita merupakan suatu cara penyampaian materi yang dapat diintegrasikan dengan dasar keterampilan berbahasa, yakni berbicara, membaca, menulis, dan menyimak dan tidak terkecuali untuk anak TK. Disamping itu, Nurbiana Dheini (2011:66) menjelaskan bahwa bercerita sebagai suatu metode merupakan memberikan suatu cerita secara lisan yang isi ceritanya mencakup materi pembelajaran.

Singkatnya, metode bercerita adalah suatu penyajian materi pembelajaran dengan membawakan cerita kepada anak secara lisan, sehingga anak mendapatkan pengalaman belajar yang menyenangkan dan ilmu pengetahuan baru lewat cerita.

Beberapa manfaat bercerita pada anak menurut Nurbiana Dhieni (2011:6-8) yaitu; (1) Melatih daya serap dan daya tangkap anak, (2) melatih daya pikir anak, (3) melatih saya konsentrasi anak, (4) mengembangkan daya imajinasi anak, (5) menciptakan situasi yang menggembirakan serta mengembangkan suasana hubungan yang akrap sesuai dengan tahap perkembangannya, (6) membantu perkembangan bahasa anak dalam berkomunikasi secara efektif dan efisien sehingga proses percakapan menjadi komunikatif.

Pendapat lain tentang manfaat bercerita juga dikemukakan oleh Moeslichatoen (2004:168) yaitu; (1) untuk menanamkan kejujuran, ketulusan, keberanian, kesetiaan, keramahan, dan sikap-sikap positif lain dalam kehidupan keluarga, (2) memberikan pengetahuan sosial, nilai-nilai moral dan keagamaan, (3) memberikan pengalaman belajar untuk melatih mendengarkan, (4) mengembangkan kemampuan kognitif, afektif, maupun psikomotor dari masing-masing anak.

Berdasarkan pendapat diatas dapat disimpulkan bahwa manfaat bercerita adalah untuk memperluas cara berpikir anak, sebab anak mendapat pengalaman baru, serta menambah pengetahuannya dan memberikan pendidikan yang positif dalam membentuk kepribadian dan moral anak yang lebih baik.

Adapun langkah-langkah kegiatan bercerita menurut Moeslichatoen (2004:179) yaitu:

1. Mengkomunikasikan tujuan dan tema dalam kegiatan bercerita,

2. Mengatur tempat duduk anak. Misalnya anak duduk dilantai dan diberi alas tikar atau karpet, atau duduk dikursi dengan formasi setengah lingkaran,

3. Pembukaan kegiatan bercerita, dimana guru menggali pengalaman-pengalaman anak dalam kaitannya dengan tema cerita,

4. Pengembangan cerita yang dituturkan guru. Guru menyajikan fakta-fakta disekitar kehidupan anak yang berkaitan dengan tema cerita,

5. Menceritakan isi cerita dengan lafal, intonasi dan ekspresi wajah yang menggambarkan suasana cerita,

6. Menutup kegiatan cerita dengan mengajukan pertanyaan-pertanyaan yang berkaitan dengan isi cerita.

Dalam penggunaan metode bercerita dalam pembelajaran dikelas perlu diperhatikan kiat-kiat yang tepat agar metode bercerita dapat dilakukan dengan maksimal. Menurut Majid (2005: 4754) "dalam bercerita guru perlu memperhatikan hal-hal sebagai berikut: (1) Tempat bercerita, (2) posisi duduk, (3) bahasa cerita, (4) intonasi guru, 
(5) Pemunculan tokoh-tokoh, (6) Penampakan emosi, (7) peniruan suara, (8) penguasaan terhadap siswa yang tidak serius, (9) menghindari ucapan spontan". Pemilihan tempat bercerita memegang peranan penting untuk keberhasilan metode bercerita ini, tidak harus selamanya dilakukan di kelas atau didalam ruangan tetapi juga dapat dilakukan di luar kelas terutama di tempat yang berhubungan langsung dengan isi cerita. Misalnya, ketika guru ingin bercerita tentang bintang maka guru dapat melakukannya langsung di kebun binatang sehingga anak langsung berinteraksi dengan binatang sesuai isi cerita.

Posisi duduk juga sangat penting karena berhubungan dengan konsentrasi anak. Duduk tidak harus selalu di kursi tetapi juga dapat dilakukan langsung dilantai dengan beralaskan tikar atau karpet sehingga anak lebih santai menikmati isi cerita. Posisi duduk juga tidak harus selalu seperti posisi belajar berbaris tetapi dapat dilakukan dengan membentuk setengah lingkaran. Hal ini dilakukan agar guru dapat mengontrol penuh anak-anak sehingga isi cerita dapat dipahami dengan baik. Bahasa yang digunakan guru ketika bercerita harus bahasa yang dekat dengan anak dan komunikatif. Bahasa yang jarang di dengar oleh anak anak menyusahkan anak dalam memahami isi cerita dan membuat anak merasa bosan. Bahasa yang digunakan sebaiknya bahasa sehari hari yang familiar dengan anak.

Dalam bercerita penggunaan intonasi yang tepat sangat mempengaruhi keberhasilan suatu kegiatan bercerita. Jika intonasi yang digunakan oleh guru ketika bercerita hanya datar saja maka isi cerita tidak sampai dengan baik kepada peserta didik dan tentunya anak akan merasa bosan. Diawal bercerita sebaiknya guru menggunakan intonasi yang tenang kemudian mengeraskannya sedikit demi sedikit. Tinggi rendahnya suara harus sesuai dengan isi cerita yang sedang di ceritakan oleh guru. Ketika sampai pada inti konflik cerita, guru dapat mengeraskan suara dengan tujuan untuk menarik perhatian dari peserta didik. Tokoh-tokoh dalam cerita harus dimunculkan secara hidup di depan anak dengan tujuan anak memiliki pengalaman secara langsung terhadap tokoh yang ada pada cerita tersebut.
Dalam bercerita mimik dan ekspresi merupakan suatu hal yang sangat penting karena sangat mempengaruhi penyampaian cerita. Ketika isi cerita sedih guru harus menunjukkan mimik wajah yang sedih, ketika isi cerita bahagia maka guru harus bercerita dengan bahagia dan ketika ada tokoh yang sedang marah pada cerita tersebut maka guru harus memerankan peran marah pada cerita. Dalam hal penyampaian mimik marah, guru harus sedikit berhati hati karena ekspresi yang berlebihan dapat membuat anak merasa takut dan menangis. Penguasaan mimik dan ekspresi dalam memerankan tokoh-tokoh dalam cerita harus benar-benar dikuasai oleh guru. Guru harus mampu memerankan setiap tokoh dengan baik. Jika tokoh pada cerita adalah hewan, misal nya kambing, maka guru harus dapat menirukan suara kambing seperti "mbekk...mbek...." dan jika tokoh pada cerita adalah ayam jantan maka guru harus dapat menirukan suara ayam seperti "kukuruyuk........ Peniruan suara ini dilakukan guru agar anak merasa tertarik mendengarkan isi cerita.

Seorang guru yang baik harus mampu menguasai seluruh siswa yang ada di dalam kelas sehingga perhatian siswa fokus pada cerita yang dibacakan. Jika terdapat siswa yang berlarian dikelas atau duduk secara berpindah-pindah maka guru perlu mendatangi satu persatu dan menarik tangannya mengajak kembali duduk dengan rapi pada tempat yang telah ditentukan.

\section{METODE}

Pada penelitian ini peneliti menggunakan desain penelitian tindakan kelas (Classroom Action Research). Kusumah dan Dwigatama (2010: 9) menyebutkan penelitian tindakan kelas adalah penelitian yang bertujuan untuk meningkatkan mutu pembelajaran di kelas, sehingga penelitian tindakan ini harus dilakukan oleh guru kelas yang bersangkutan. Dalam penelitian tindakan kelas, guru atau peneliti harus melaksanakan tahapan perencanaan penelitian, pelaksanaan penelitian tindakan, serta merefleksikan proses penelitian tindakan secara kolaboratif dan partisipatif. Dalam penilitian ini peneliti bekerjasama dengan 
dengan guru kelas kelompok B di TK Mawar Indah sebagi guru peneliti.

Penelitian tindakan ini adalah kolaborasi antara peniliti dengan guru kelas kelompok B di TK Mawar Indah. Peneliti aktif berpartisipasi dalam merencanakan dan melaksanakan penelitian, juga pelaksanaan observasi dan refleksi selama dan setelah penelitian tindakan dilaksanakan. Selanjutnya, selama pelaksanaan penelitian peneliti memantau, mencatat dan mengumpulkan data lalu menganalisa data yang telah dikumpulkan hingga akhirnya melaporkan hasil penelitian tindakan. Penelitian ini dilaksanakan di TK Mawar indah di jalan Pasundan Gg. Dewi No. 29 D/45 G, kel. Sei Putih Timur II, Kec. Medan Petisah, Kota Medan. Subjek penelitian adalah seluruh siswa kelompok B pada rentan usia 5-6 Tahun yang berjumlah 20 Orang.

Penelitian ini dilaksanakan pada semester Genap T.A 2017/2018 selama satu bulan yang terdiri Dari dua siklus yaitu siklus I dan siklus ke II. Desain penelitian yang dilaksanakan yaitu model Kemmis dan Mc. Teggart yang digambarkan oleh Arikunto (2010) yaitu sebagai berikut:

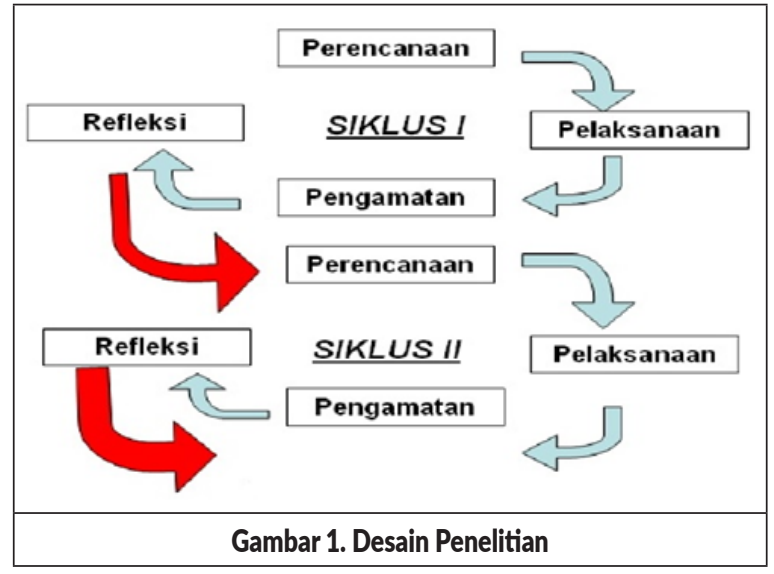

Dalam penelitian ini, dua siklus yang dilakukan oleh peneliti meliputi Perencanaan, Pelaksanaan/Tindakan, Pengamatan dan Refleksi. Siklus pertama dalam penelitian ini menggunakan tindakan metode bercerita tetapi tanpa menggunakan media dan menggunakan metode ceramah yang biasa digunakan guru di TK Mawar Indah dalam proses belajar mengajar. Dalam hal ini peneliti menyusun tempat duduk secara klasikal. Berdasarkan Pelaksanaan/tindakan pada siklus I dilakukan perbaikan pada pelaksanaan tersebut. Perbaikannya guru juga yang menginstruksikan bagaimana cara melakukan prosedur bercerita yang akan dilakukan oleh anak pada siklus I yang sekaligus akan digunakan pada siklus II.

Rangkaian kegiatan siklus-siklus dalam penelitian tindakan ini sebagai berikut:

a. Membuat Rencana Kegiatan Harian dan menyiapkan cerita untuk dibawakan dalam pembelajaran sebagai materi menyimak, menyiapkan alat dan bahan penelitian tindakan.

b. Melaksanakan dan mengamati proses penelitian tindakan

c. Melakukan refleksi di akhir pertemuan untuk menentukan langkah selanjutnya.

d. Jika perbaikan dirasa perlu, maka dilaksanakan di minggu selanjutnya.

Pelaksanaan dalam siklus ini yaitu mencakup 4 hal, yaitu:

Pada Tahap Perencanaan, Proses perencanaan yang dilakukan oleh peneliti dan guru kelas dimulai dengan pengkajian kurikulum sebagai pedoman pelaksanaan penelitian tindakan. Kemudian, guru dan peneliti merancang rencana pelaksanaan pembelajaran dengan tema alam semesta dan sub tema hewan (kupu-kupu), menyusun rencana kegiatan harian, dan menyiapkan alat dan media yang akan digunakan untuk kegiatan bercerita, menyiapkan lembar observasi dan alat perekam (kamera) untuk mendokumentasikan kegiatan anak-anak selama proses belajar mengajar.

Pada Tahap Pelaksanaan, Dalam penelitian tindakan ini peneliti bertindak sebagai guru dan dua orang guru kelas sebagai pengamat dan memberi kritik dan saran untuk proses selanjutnya. Kegiatan yang dilakukan adalah melaksanakan pembelajaran yang telah disusun dengan menonjolkan kegiatan yang ingin di terapkan yaitu menggunakna metode bercerita tetapi tanpa alat peraga dan metode ceramah, peneliti melihat kemampuan anak dengan menggunakan metode bercerita tetapi dengan cara yang biasa. Tahap pelaksanaan terdiri dari tiga kegiatan yaitu kegiatan awal, kegiatan inti dan kegiatan akhir.

Kegiatan awal dalam tahap ini guru mengkondisikan tempat duduk anak yang dibagi menjadi tiga kelompok agar siswa relaks dalam 
mengikuti pembelajaran. Proses pelaksanaan pembelajaran ini mengacu pada rencana pelaksanaan pembelajaran harian yang telah disiapkan. Pada kegiatan inti siswa mengerjakan tugas yang diberikan guru dan mendengar cerita dari guru. Kemudian pada tahap akhir, guru membimbing siswa untuk mengulas kembali dan menarik kesimpulan dari pembelajaran yang telah dilakukan dengan cara melakukan tanya jawab. Kegiatan ini dilakukan untuk mengukur tingkat pemahaman siswa terhadap cerita yang disampaikan.

Pada Tahap Observasi, Observasi atau pengamatan selama proses pelaksanaan berlangsung akan dilakukan oleh guru kelas. Tujuan dari observasi adalah untuk mengukur kesesuaian pelaksanaan pembelajaran dengan rencana yang telah disusun, serta mengidentifikasi apa saja yang sudah dicapai dan apa yang harus diperbaiki. Objek yang cukup vital dalam observasi ini adalah aktifitas anak-anak dalam proses menyimak.

Pada Tahap Refleksi, Refleksi adalah proses evaluasi terhadap apa yang telah dilakukan selama proses pembelajaran serta mengolah data yang didapatkan dari penelitian sehingga dapat ditarik kesimpulan untuk melaksanakan siklus berikutnya jika harus ada perbaikan ataupun menyudahi siklus jika hasil siklus telah mencapai target.

Pengambilan data dalam penelitian ini menggunakan beberapa instrumen. Instrumen adalah alat pengambilan data yang diperlukan dalam penelitian tindakan. Arikunto (2005:101) dalam bukunya menjelaskan bahwa instrumen penelitian harus bersifat sistematis dan memudahkan peneliti dalam mengumpulkan data agar data yang didapat sesuai dengan yang dibutuhkan peneliti. Dalam penelitian ini seorang peneliti harus mampu menyusun instrumen yang sesuai dengan pembelajaran menyimak dan aktifitas siswa selama menyimak cerita.

Instrumen yang biasa digunakan dalam penelitian adalah observasi. Harsono (2011:48) menyebutkan bahwa dengan observasi peneliti akan mendapatkan data dan informasi yang cukup akurat karena peneliti harus terlibat langsung dalam proses observasi.
Oleh karena itu, peneliti dan guru kolaborator akan menggunakan instrumenlembar observasi berupa check list untuk mengontrol setiap tahapan pelaksanaan pembelajaran kamera untuk mendokumentasikan kegiatan menyimak. Selain lembar check list peneliti dan kolaborator mencatat kejadian-kejadian penting selama proses pembelajaran berlangsung ataupun melalui video dokumentasi setelah pembelajaran.

Data yang telah berhasil dikumpulkan melalui observasi, dokumentasi dan field note akan diolah dan dianalisis untuk mengukur keberhasilan pembelajaran dan menguji hipotesis dari penelitian ini. Stainback (2007: 244) menuturkan bahwa dalam penelitian kuantitatif ataupun kualitatif harus menggunakan teknik analisis data yang sesuai. Penelitian ini menggunakan teknik analisis deskriptif kuantitaf. Menurut Arikunto (2010: 43) teknik analisis untuk penelitian kuantitatif menggunakan predikat, bukan hanya dengan angka.

\section{HASIL dan PEMBAHASAN}

Penelitian ini dilangsungkan sebanyak dua siklus. Peneliti dan guru kolaborator telah melaksanakan seluruh tahapan pada setiap siklus, dan berhasil mendapatkan data yang dibutuhkan dalam penelitian tindakan kelas ini, yaitu dari hasil observasi dan dokumentasi kegiatan bercerita dan menyimak. Pengolahan data ini bertujuan untuk memastikan adanya peningkatan sebelum dan sesudah pemberian tindakan bercerita dalam proses pembelajaran menyimak anak. Kondisi awal kemampuan menyimak anak berada pada kriteria mulai berkembang atau cukup. Untuk memperbaiki permasalahan yang berkaitan dengan kemampuan menyimak anak kelompok B TK Mawar Indah, maka kegiatan pembelajaran dilakukan melalui metode bercerita.

Pengamatan yang dilakukan oleh peniliti hanya pada tahap pra tindakan sebelum siklus I. Pra Tindakan dilakukan untuk mengetahui keadaan awal kemampuan menyimak anak kelompok B TK Mawar Indah Kecamatan Medan Petisah yang dilaksanakan pada tanggal 30 April 2018. Pada kegiatan pra tindakan peneliti belum membentuk posisi duduk anak, anak masih du- 
duk secara klasikal. Sehingga pada saat peneliti membacakan cerita sikap anak acuh tak acuh, mengobrol dengan teman bahkan jahil terhadap teman sekelasnya. Selain itu, ketika guru bertanya tentang pelajaran anak tidak mampu menjawab dan menjelaskan cerita yang baru saja dibacakan.

Kegiatan pra tindakan ini memuat tema binatang dengan subtema kupu-kupu yang dilakukan peneliti dengan menggunakan media buku cerita. Hasilnya terlihat bahwa perkembangan kemampuan menyimak siswa Kelompok B TK Mawar Indah sangat rendah. Hal ini terlihat dari jumlah keseluruhan rata-rata anak dalam menyimak $42,5 \%$. Pencapaian tersebut terindikasi cukup, oleh karena kemampuan menyimak anak berlum dikatakan berhasil. Hasil pengamatan kondisi awal saat anak disuruh untuk mendengarkan cerita yang disampaikan oleh peneliti, anak masih banyak yang belum dapat mendengarkan dan menyimak dengan baik.Masih ada yang bercerita dan belum memperhatikan peneliti. Hal ini juga terlihat pada saat peneliti selesai bercerita dan bertanya tentang judul dan tokoh-tokoh yang ada didalam cerita anak masih kurang mampu menyimak dan menjawab dengan benar pertanyaan yang disampaikan oleh peneliti. Hal ini terlihat pada tabel berikut.

\begin{tabular}{|c|c|c|c|c|c|}
\hline No & Pertemuan & Jumlah Skor & Jumlah Anak & $\begin{array}{l}\text { Persentase } \\
\text { Rat-rata }\end{array}$ & Kriteria \\
\hline 1 & Pertindakan & 850 & 20 & $42,5 \%$ & Cukup \\
\hline
\end{tabular}

Selanjutnya pada siklus I pembelajaran pertemuan pertama, peneliti menceritakan isi cerita bergambar yang berjudul "Ulat dan Bunga Matahari”.Anak-anak merasa antusias untuk memperhatikan peneliti yang sedang bercerita. Namun ketika peneliti bertanya kepada anakanak mengenai cerita tersebut, hanya sebagian anak saja yang menjawab dan ada juga anak yang duduk mendengarkan namun ketika ditanya si anak tersebut tidak mau menjawab.

Hasil Siklus I menunjukkan rata-rata kemampuan anak 76,25\%, yang berarti bahwa ada peningkatan yang cukup signifikan, tetapi masih dalam kriteria cukup. Oleh sebab itu, guru kolaborasi dan peneliti memutuskan untuk meneruskan penelitian di siklus II, dengan harapan anak mampu mengurutkan gambar cerita dan menceritakan kembali isi cerita sederhana yang sudah diceritakan oleh peneliti.

\begin{tabular}{|c|c|c|c|c|c|}
\hline \multicolumn{5}{|c}{ Tabel 2. Pencapaian Kemampuan Anak Pada Siklus I } \\
\hline No & Pertemuan & Jumlah Skor & Jumlah Anak & $\begin{array}{c}\text { Persentase } \\
\text { Rat-rata }\end{array}$ & Kriteria \\
\hline 1 & Siklus I & 1.525 & 20 & $76,25 \%$ & Baik \\
\hline
\end{tabular}

Hasil di atas menunjukkan pencapaian keterampilan menyimak anak di tahap pratindakan berada di angka 42,5\%, kemudian di Siklus I meningkat menjadi 76,25\%., dan selisihnya yaitu $33,75 \%$.

Selanjutnya pada siklus II, Langkah tindakan Siklus II ini pada prinsipnya sama dengan pelaksanaan tindakan Siklus I, namun pada siklus II ini peneliti melakukan metode bercerita dengan merubah posisi tempat duduk dengan bentuk setengah lingkaran, sehingga anak secara keseluruhan dapat melihat peneliti membacakan cerita dengan jelas.

Siklus II ini memuat tema binatang dengan subtema kupu-kupu. Indikator pembelajaran pada Siklus II ini yaitu anak dapat mengurutkan gambar cerita dan menceritakan kembali isi cerita sederhana yang sudah diceritakan oleh guru secara sederhana.

Hasil pengamatan pada Siklus II dapat dijelaskan bahwa anak dapat menjawab pertanyaan dan sudah mampu mengurutkan gambar cerita dan menceritakan sedikit isi cerita dengan sederhana. Anak mulai terbiasa dengan metode bercerita dan gambar-gambar yang ditunjukkan oleh peneliti. Sehingga anak sudah mampu mengingat dan menyimak isi cerita bergambar yang disampaikan oleh peneliti.

Ketika peneliti bertanya pada anak bagaimana cerita "ulat dan bunga matahari" anak dapat menceritakan kembali karena mereka telah memperhatikan dan menyimak apa yang sudah disampaikan oleh peneliti.

Tabel 3. Pencapaian Kemampuan Menyimak Anak Pada Siklus II
\begin{tabular}{|c|c|c|c|c|c|}
\hline No & Pertemuan & Jumlah Skor & Jumlah Anak & $\begin{array}{c}\text { Persentase } \\
\text { Rat-rata }\end{array}$ & Kriteria \\
\hline 1 & Siklus II & 1.950 & 20 & $97,5 \%$ & Sangat Baik \\
\hline
\end{tabular}

Hasil di Siklus II terlihat jauh lebih baik dari tahap Pra Tindakan dan Siklus I, persentase ratarata kemampuan menyimak siswa mencapai 97,5 
$\%$ dan sudah memenuhi kriteria sangat baik (81\% $-100 \%)$.

Hasil dari Siklus I dan II menunjukkan ratarata $76,25 \%$, dan $97,5 \%$, dengan selisish $21,25 \%$. Dari hasil di atas bisa ditarik kesimpulan anak kelompok B TK Mawar Indah tidak hanya mampu menyimak, tetapi juga mampu memberi kesan dan pengetahuan yang baru pada isi dan gambar dalam cerita. Dari hasil yang sudah mencapai keberhasilan ini, peneliti dan guru kolaborator memutuskan untuk tidak melanjutkan siklus.

\section{Analisis Data}

Hasil dari penilaian kemampuan menyimak anak pada penelitian ini cenderung meningkat di setiap kegiatan. Hasil pencapaian kemampuan menyimak anak Pratindakan, Siklus I, dan Siklus II disajikan dalam tabel berikut:

\begin{tabular}{|c|c|c|c|}
\hline \multicolumn{5}{c}{$\begin{array}{c}\text { Tabel 4. Capaian Kemampuan Menyimak Anak } \\
\text { di Tahap Pra Tindakan, Siklus I, dan Siklus II }\end{array}$} \\
\hline No & Kegiatan & Rata-rata Persentase & Kriteria \\
\hline 1 & Pra Tindakan & $42,5 \%$ & Cukup \\
\hline 2 & Siklus I & $76,25 \%$ & Baik \\
\hline 3 & Siklus II & $97,5 \%$ & Sangat Baik \\
\hline
\end{tabular}

Berdasarkan tabel di atas, hasil tindakan di Siklus II terlihat meningkat dari pra tindakan dan siklus 1 . Hal ini berarti bahwa dalam penelitian tindakan kelas ini kemampuan menyimak anak berhasil ditingkatkan sebanyak 33,75\% dan $21,25 \%$ di siklus i dan siklus II, dengan rata-rata akhir berada di persentase $97.5 \%$ yang memenuhi kriteria sangat baik, sehingga tidak memerlukan siklus lanjutan.

\section{SIMPULAN}

Berdasarkan hasil penelitian dan pembahasan, dapat diambil kesimpulan bahwa penggunaan metode bercerita dapat meningkatkan kemampuan menyimak anak kelompok B TK Mawar Indah. Hasil penelitian menunjukkan bahwa di Siklus I kemampuan menyimak anak meningkat sebanyak $33,75 \%$, dan meningkat lagi sebanyak $21,25 \%$ di Siklus II sampai ada di titik 97,5 5 yang berarti bahwa kemampuan menyimak anak sangat baik. Kriteria sangat baik yaitu semua anak sudah mampu mengurutkan gambar cerita dan menceritakan sedikit isi cerita dengan sederhana.

Penggunaan metode bercerita dalam pembelajaran di kelas mampu untuk meningkatkan kemampuan menyimak anak usia 5-6 tahun dengan kegiatan mengurutkan isi cerita dan menceritakan gambar bergambar. Pelaksanaan pembelajaran dengan metode bercerita yaitu menjelaskan semua gambar pada media buku cerita bergambarkepada anak dan menyampaikan pesan yang ingin disampaikan dari buku cerita tersebut.

Penggunaan metode bercerita memudahkan anak untuk belajar menyimak dan mengolah informasi yang didengar, serta memahami isi dari cerita tersebut dengan membayangkan kejadian demi kejadian dalam cerita.

\section{DAFTAR PUSTAKA}

Rahmat, A., dkk. (2016). Pengaruh Metode Bercerita Terhadap Kemampuan Menyimak Anak Di Kota Selatan Gorontalo. Journal of Nonformal Education and Community Empowerment), JNFC 5 (1)

Akhadiah, Sabarti, dkk. (1992). Bahasa Indonesia III. Jakarta. Proyek Pembinaan Tenaga Kependidikan.

Anderson, R. C. (1972). Language Skills in Elementary Education. NewYork. Macmillan Publishing Co, Inc

Azizah,. 2015. Kecerdasan Emosional/Emotional Inteligent $\mathrm{EQ}$.

Bromley, K. D. (1992). Language Art: Exploring Connection (2nd ed). Boston. Allyn and Bacon.

Cahyani, I., \& Hodijah. (2007). Kemampuan Berbahasa Indonesia di Sekolah Dasar. Bandung. UPI Press

Octivasari, F. (2016). Pengaruh Bercerita Terhadap Keterampilan Menyimak Pada Anak Usia 5-6 Tahun di TK AL-AKBAR, Kec Beringin Kab. Deli Serdang tahun ajaran 2015-2016. Medan. Universitas Negeri Medan.

Tarigan, G., \& Henry. (1980). Menyimak Sebagai Suatu Keterampilan Berbahasa. Bandung. Penerbit Angkasa. 
Tarigan, G., \& Henry. (2008). Menyimak. Bandung: Angkasa

Tarigan, G., \& Henry. (1986). Menyimak Sebagai Suatu Keterampilan Berbahasa. Bandung. Angkasa

Logan, L.M., Logan, V., G. (1992). Creative Communication. Toronto. Mc

Emayanti, L.W., dkk. (2017). Pengaruh Metode Bercerita Bermediakan Audio Visual Pembelajaran Terhadap Kemampuan Menyimak Anak Gugus III Kecamatan Buleleng. Journal Pendidikan Anak Usia Dini Universitas Pendidikan Ganesha, Volume 5 No.1

Majid, A. (2005). Perencanaan Pembelajaran Mengembangkan Standar Kompetensi Guru. Bandung. Remaja Rosdakarya

Marhijanto, B. (1995). Kamus Lengkap Bahasa Indonesia Popular. Bandung. Buku Pintar Transaksi Syariah

Moeslichatoen. (2004). Metode Pengajaran Di Taman Kanak-Kanak. Jakarta. Penerbit PT Rineka Cipta.

Sudjana, N. (1996). Cara Belajar Siswa Aktif
Dalam Proses Belajar Mengajar. Bandung. Sinar Baru Algesindo

Sudjana, N., \& Suwariyah, W.(2010). Modelmodel Mengajar CBSA. Bandung. Sinar Baru Algesindo

Dhieni, N.,dkk. (2011). Metode Pengembangan Bahasa. Jakarta. Universitas Terbuka.

Risaldy, S. (2015). Bermain, Bercerita, dan Menyanyi Bagi Anak Usia Dini. Jakarta Timur. PT Luxima Metro Media.

Sugiyono. (2012). Metode Penelitian Kombinasi (Mixed Methods). Bandung. Penerbit Alfabeta.

Sugiyono. (2015). Metode Penelitian Pendidikan. Bandung: Alfabeta

Arikunto, S. (2010). Prosedur Penelitian Suatu Pendekatan Praktik. Jakarta. Penerbit Rineka Cipta.

Tampubolon. (1991). Mengembangkan Minat dan Kebiasaan Membaca Pada Anak. Bandung. UPI Press

Sujiono, Y. N. (2009). Konsep Dasar Pendidikan Anak Usia Dini. Jakarta. PT. Indeks. 